\title{
Phylogenetic Diversity of Archaea in Shallow Hydrothermal Vents of Eolian Islands, Italy
}

\author{
Concetta Gugliandolo *(D) and Teresa L. Maugeri \\ Department of Chemical, Biological, Pharmaceutical and Environmental Sciences, Research Centre for Extreme \\ Environments and Extremophiles, University of Messina, 98122 Messina, Italy \\ * Correspondence: cgugliandolo@unime.it
}

Received: 16 July 2019; Accepted: 3 September 2019; Published: 5 September 2019

\begin{abstract}
Shallow hydrothermal systems (SHS) around the Eolian Islands (Italy), related to both active and extinct volcanism, are characterized by high temperatures, high concentrations of $\mathrm{CO}_{2}$ and $\mathrm{H}_{2} \mathrm{~S}$, and low $\mathrm{pH}$, prohibitive for the majority of eukaryotes which are less tolerant to the extreme conditions than prokaryotes. Archaea and bacteria are the key elements for the functioning of these ecosystems, as they are involved in the transformation of inorganic compounds released from the vent emissions and are at the basis of the hydrothermal system food web. New extremophilic archaea (thermophilic, hyperthermophilic, acidophilic, alkalophilic, etc.) have been isolated from vents of Vulcano Island, exhibiting interesting features potentially valuable in biotechnology. Metagenomic analyses, which mainly involved molecular studies of the $16 \mathrm{~S}$ rRNA gene, provided different insights into microbial composition associated with Eolian SHS. Archaeal community composition at Eolian vent sites results greatly affected by the geochemistry of the studied vents, principally by hypersaline conditions and declining temperatures. Archaeal community in sediments was mostly composed by hyperthermophilic members of Crenarchaeota (class Thermoprotei) and Euryarchaeota (Thermococci and Methanococci) at the highest temperature condition. Mesophilic Euryarchaeota (Halobacteria, Methanomicrobia, and Methanobacteria) increased with decreasing temperatures. Eolian SHS harbor a high diversity of largely unknown archaea, and the studied vents may be an important source of new isolates potentially useful for biotechnological purposes.
\end{abstract}

Keywords: Archaea; archaeal diversity; PCR/DGGE; Illumina sequencing; shallow hydrothermal systems

\section{Introduction}

Marine hydrothermal systems (shallow and deep-sea vents) are associated with areas of active submarine volcanism and occur at mid-oceans ridges, inland arcs, and submerged volcanoes at both shallow and deep-sea locations, which are currently defined by a cut off at a depth of $200 \mathrm{~m} \mathrm{[1]}$, that coincides with the limit of the photic zone. The hydrothermal conditions considerably influence the chemical and biological properties of the surrounding environments, which result prohibitive for most organisms. In contrast, hydrothermal conditions have a low impact on prokaryotes (bacteria and archaea), which are able to tolerate both the strong physical and chemical gradients and the so-called extreme conditions. Archaea and bacteria exert a pivotal role in the functioning of the hydrothermal ecosystems, since they are involved in the transformation of inorganic compounds released from vent emissions into biomass and therefore, they are at the basis of the hydrothermal system food web $[2,3]$. Since many archaea were firstly isolated from thermal springs or deep-sea hydrothermal vents, they have been considered as organisms restricted to extreme environments, although they are now known to be widespread throughout the oceans, where they constitute a relevant fraction of the microbial community [4-7]. Despite the success in culturing heat-loving archaea and bacteria from hydrothermal vents, where the fluid temperature can reach very high temperatures, most of the microbial diversity 
is still known only as gene sequences. The limited number of archaeal isolates greatly limits our knowledge of their metabolic pathways, and therefore we cannot fully interpret their biochemistry and physiology, and consequently, their impact on biogeochemical cycles, ecological significance, and their role within the ecosystems are until now largely unknown.

The Mediterranean Sea hosts several shallow hydrothermal systems (SHS), of which those located on the Eolian Islands (Italy) [8-15] and the Aegean Volcanic Arc (Greece) [16-18] have been studied for over more than a decade. Shallow hydrothermal systems sustain a more complex microbial community than deep-sea vents, since both sunlight and hydrothermal energy support both photosynthetic and chemosynthetic organisms [19-22]. Although their ubiquitous distribution in tectonically active coastal zones, microbial communities associated with SHS have been less investigated than deep-sea vents.

The SHS off the Eolian Islands (Italy), characterized by high temperatures, high concentrations of $\mathrm{CO}_{2}$, and low $\mathrm{pH}$, provide excellent natural fields to investigate how microorganisms respond to potential global changes, and to study the effects of increasing temperature and acidification in the oceans. Such ecosystems represent valuable sources of so far unknown types of extremophiles potentially useful for biotechnological purposes.

Here, we compare the phylogenetic diversity of archaeal groups in shallow hydrothermal vents of Eolian Islands using recent results and insights from metagenomic approaches. The incredible uncultivated diversity in Eolian SHS suggests there is much more to be done.

\subsection{Diversity of Archaea as Currently Known}

The archaea were phylogenetically distinguished from the bacteria in 1977, when Carl Woese and Fox [23] revolutionized phylogeny by comparing conserved small subunit (16S and 18S) ribosomal RNA (rRNA) sequences. Successively, archaea were divided into two groups with the taxonomic rank of kingdoms: the Crenarchaeota, all hyperthermophilic, and the Euryarchaeota, containing species with a variety of phenotypes (hyperthermophilic, mesophilic, methanogenic, and halophilic) (Woese et al. 1990) [24]. There are many debates for taxonomy of archaea, since several possible novel phyla have been also proposed only based on phylogenetic analyses in metagenomic or single cell genomic studies. More recently, phylogenetic analyses have supported a clade uniting the Thaumarchaeota, Aigarchaeota, Crenarchaeota, and Korarchaeota which has been informally named the "TACK" archaea [25] or "Proteoarchaeota" [26]. A novel candidate archaeal phylum, Lokiarchaeota, was described as related to the TACK superphylum, representing the nearest relative of eukaryotes in phylogenomic analyses [27]. Other superphyla of Euryarchaeota actually include DPANN (Diapherotrites, Parvarchaeota, Aenigmarchaeota, Nanoarchaeota, Nanohaloarchaeota, Woesearchaeota, Pacearchaeota, and potentially Altiarchaea) and the more recently described Asgards (in Norse mythology, one of the Nine Worlds, home to the Æsir gods) consisting of Lokiarchaeota, Thorarchaeota, Odinarchaeota, and Heimdallarchaeota [28-30].

Members of Crenarchaeota phylum were initially believed to be mostly thermophilic, sulphur-metabolizing archaea, but their detection in different environments of oceans indicated that this domain is more widely distributed than previously assessed [31]. Crenarchaeota are generally the most abundant component of archaea populations in oxygenated deep waters [32,33] and surface sediments, surpassing the Euryarchaeota abundances of ca. fivefold [34,35]. Thaumarchaeota, embracing mesophilic Crenarchaeota [36], with the genera Cenarchaeum and Nitrosopumilus, are numerically dominant in deep marine waters and in non-diffuse flow hydrothermal vents than in normal deep and surface marine waters [37-39]. The Korarchaeota were detected in hydrothermal springs by using culture-independent molecular techniques [40] and the first genome of Candidatus Korarchaeum cryptofilum was physically isolated from an enrichment culture inoculated with sediments from Obsidian Pool, Yellowstone [41].

The Euryarchaeota phylum comprises methanogens (e.g., genera Methanococcus and Methanothermus), methanotrophs, extreme halophiles (e.g., genera Halococcus and Halobacterium), and extreme thermophiles, such as Archaeoglobus and Thermococcus. The Nanoarchaeaota have been 
recognized as a group in Euryarchaeota [42], represented by single co-cultured and characterized isolates Nanoarchaeum equitans, an ultra-small ectosymbiont residing on the marine hyperthermophilic crenarchaeote Ignicoccus hospitalis [43], Nanopusillis acidilobi, hosted by Acidilobus from a terrestrial geothermal environment [44], and the more recently described Nanoclepta minutus, hosted by Zestosphaera tikiterensis from a New Zealand hot spring [45].

\subsection{Characteristics of Thermo- and Hyperthermophilic Cultivated Archaea}

In the respect of temperature conditions, several archaeal genera are thermophilic (with optimal growth temperature $>60^{\circ} \mathrm{C}$ ), and most of them also hyperthermophilic (with optimal growth at $>80^{\circ} \mathrm{C}$ ) (Table 1) [46-54], while only two orders of bacteria, Thermotogales and Aquificales, are known to grow optimally above $80^{\circ} \mathrm{C}$.

Table 1. Some characteristics of archaea that grow above $70^{\circ} \mathrm{C}$. The genera, optimal growth temperatures, type of metabolism (A: autotrophic, H: heterotrophic, FA facultatively autotrophic), and electron acceptors are provided for each listed order.

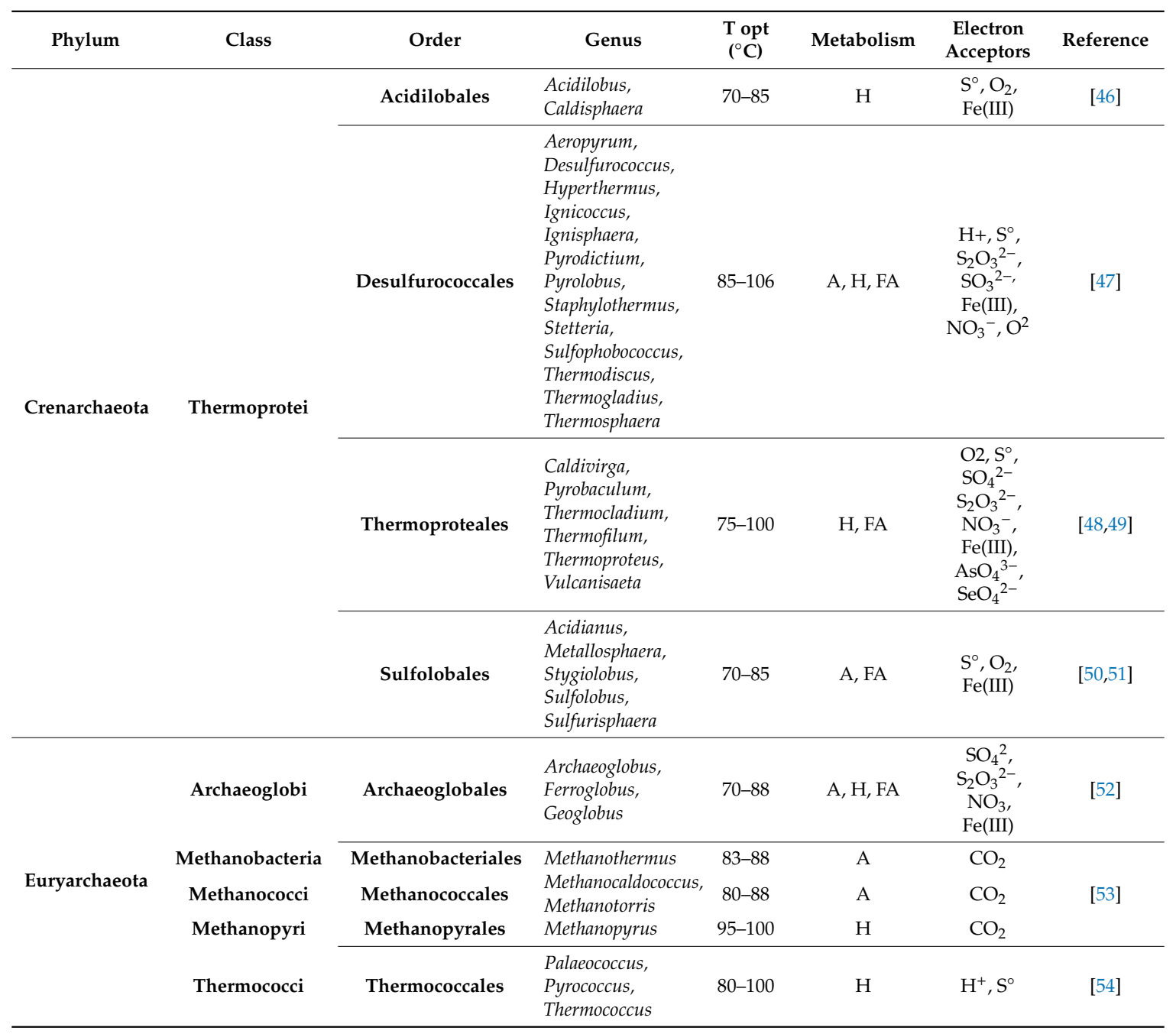

An extremely piezophilic strain of Pyrococcus yayanosii was isolated from the deep hydrothermal field of Ashadze [55]. The highest temperature at which Methanopyrus kandleri can grow under concomitant elevated pressure is $122^{\circ} \mathrm{C}[56]$. 


\section{Eolian Shallow Hydrothermal Systems}

The Eolian Archipelago (Tyrrhenian Sea, Italy), located at $25 \mathrm{~km}$ north of Sicily, consisting of seven main islands (Figure 1), hosts numerous SHS related to both active and extinct volcanism, at a depth allowing investigations by scuba divers.

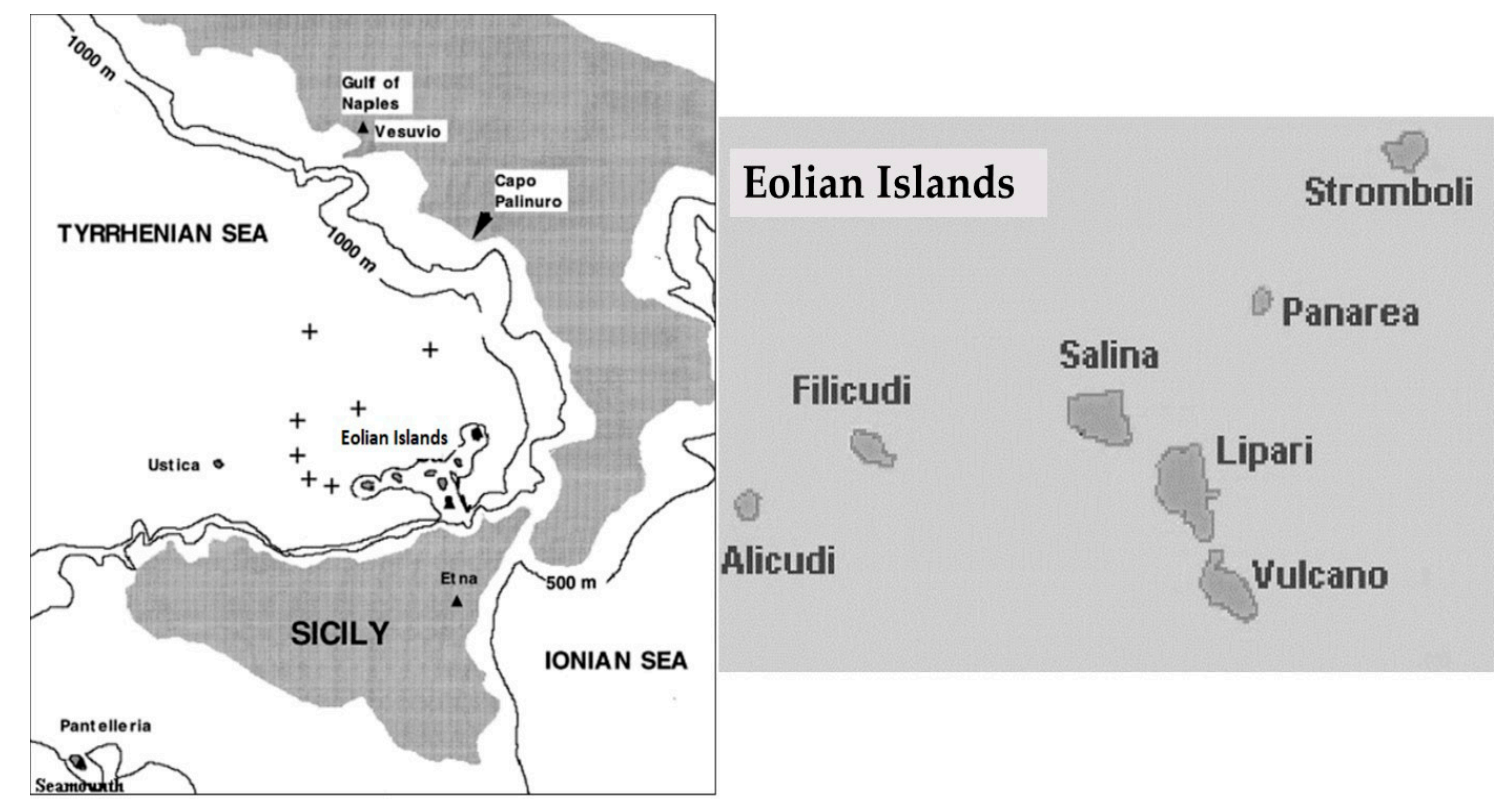

Figure 1. Hydrothermal areas in the Tyrrhenian Sea and the Eolian Islands (Italy).

At present, significant volcanic manifestations exist on only two of the Eolian Islands: Vulcano with fumarolic activity at the crater of La Fossa, and Stromboli with permanent explosive (strombolian) activity at the homonymous crater.

Submarine hydrothermal vents, common to all Eolian Islands, release both thermal waters and gases whose temperatures, detected at the emission points, are in the range of $27-130{ }^{\circ} \mathrm{C}$. Elemental sulfur is a common mineral found in sediments around the vents. Fluids diffusely escape from open fractures of the rocks or diffuse through the sand from the sea-floor. The hydrothermal fluids might emit significant amounts of heavy metals that can precipitate around the vents. On the basis of the geochemistry of the emitted fluids, Italiano [57] proposed the existence of geothermal systems beneath all the Eolian Islands, and estimated the deep temperature to be in the range of $150-350{ }^{\circ} \mathrm{C}$. The fluid composition is similar to those of deep-sea hydrothermal vents, and gases consist mostly of $\mathrm{CO}_{2}$ plus variable concentrations of the reactive gases $\mathrm{H}_{2} \mathrm{~S}, \mathrm{O}_{2}, \mathrm{CH}_{4}, \mathrm{CO}$, and $\mathrm{H}_{2}$, as well as inert gases $\left(\mathrm{N}_{2}, \mathrm{Ar}, \mathrm{He}\right)$. The $\mathrm{pH}$ values range between 1.9 and 5.7 [58-60].

\subsection{Vulcano Island SHS}

Levante Harbor of Vulcano Island is a shallow bay (Figure 2) where venting and diffuse emissions of hydrothermal fluids are easily visible. 


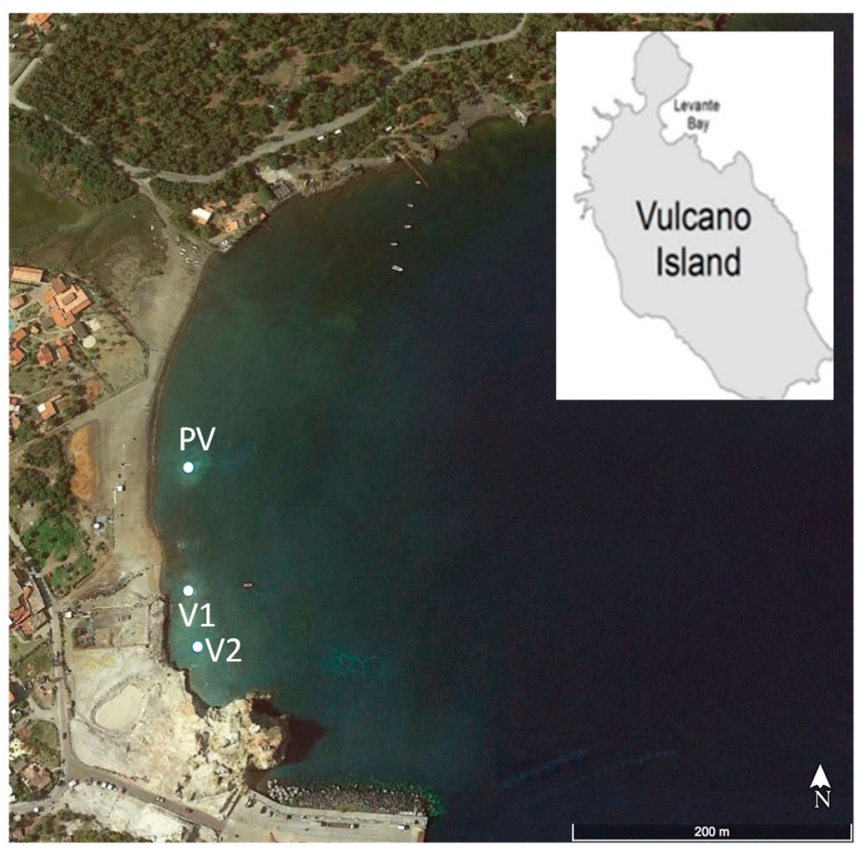

Figure 2. Levante Harbor at Vulcano Island and sampling site locations: V1, V2, and PV.

Characteristics of sampling sites are reported in Table 2.

Table 2. Main features of the fluids vented at Levante Harbor, Vulcano Island.

\begin{tabular}{cccccccccc}
\hline \multicolumn{7}{c}{ Physical and Chemical Composition of Fluid } \\
\hline Site and Sample & $\begin{array}{c}\text { Depth } \\
(\mathbf{m})\end{array}$ & $\mathbf{T}\left({ }^{\circ} \mathbf{C}\right)$ & $\mathbf{p H}$ & $\begin{array}{c}\text { Conductivity } \\
(\mathbf{m S} / \mathbf{c m})\end{array}$ & $\begin{array}{c}\mathbf{C O}_{\mathbf{2}} \\
\mathbf{( \% )}\end{array}$ & $\begin{array}{c}\mathbf{O}_{\mathbf{2}} \\
\mathbf{( \% )}\end{array}$ & $\begin{array}{c}\mathbf{H}_{\mathbf{2}} \mathbf{S} \\
\mathbf{( \% )}\end{array}$ & Reference \\
\hline Levante Harbor & 6 & $32-38$ & $4.4-6.3$ & 47.9 & nd & bdl-5.7 & bdl-8.4 & {$[8]$} \\
V1 & 2 & 35 & 6.1 & 47.9 & 1010 & 0.6 & 1.8 & {$[61]$} \\
V2 & 0.8 & 60 & 5.8 & 48.8 & 992 & 0.2 & 5.1 & nd & {$[62]$} \\
PV & 1 & 60 & 6.4 & 39.1 & nd & 6.5 & bdl & {$[9]$} \\
Reference Site & Sea level & 15 & 8.1 & 54.0 & 0.24 & 4.8 & \\
\hline
\end{tabular}

bdl: below the detection limit. nd: not determined.

The studied vents of Vulcano Island showed values really variable along the sampling sites. In particular $\mathrm{pH}$ showed an increasing range from value of 5.8 (site V2) to value of 8.1 at the reference site, not influenced by the vent area.

\subsection{Panarea Island SHS}

The submarine hydrothermal system off Panarea Island hosts the most active vents of the whole Mediterranean area and has been studied since the mid 1980s. The interest in the area around the Panarea Island increased since November 2002 when a great exhalative event occurred. The volcanic structure has evolved in recent geological times following different stages of activity: First, the central apparatus developed with the Island of Panarea, then the volcanic structure enlarged to the East by a fault system NE-SW oriented (Figure 3). 


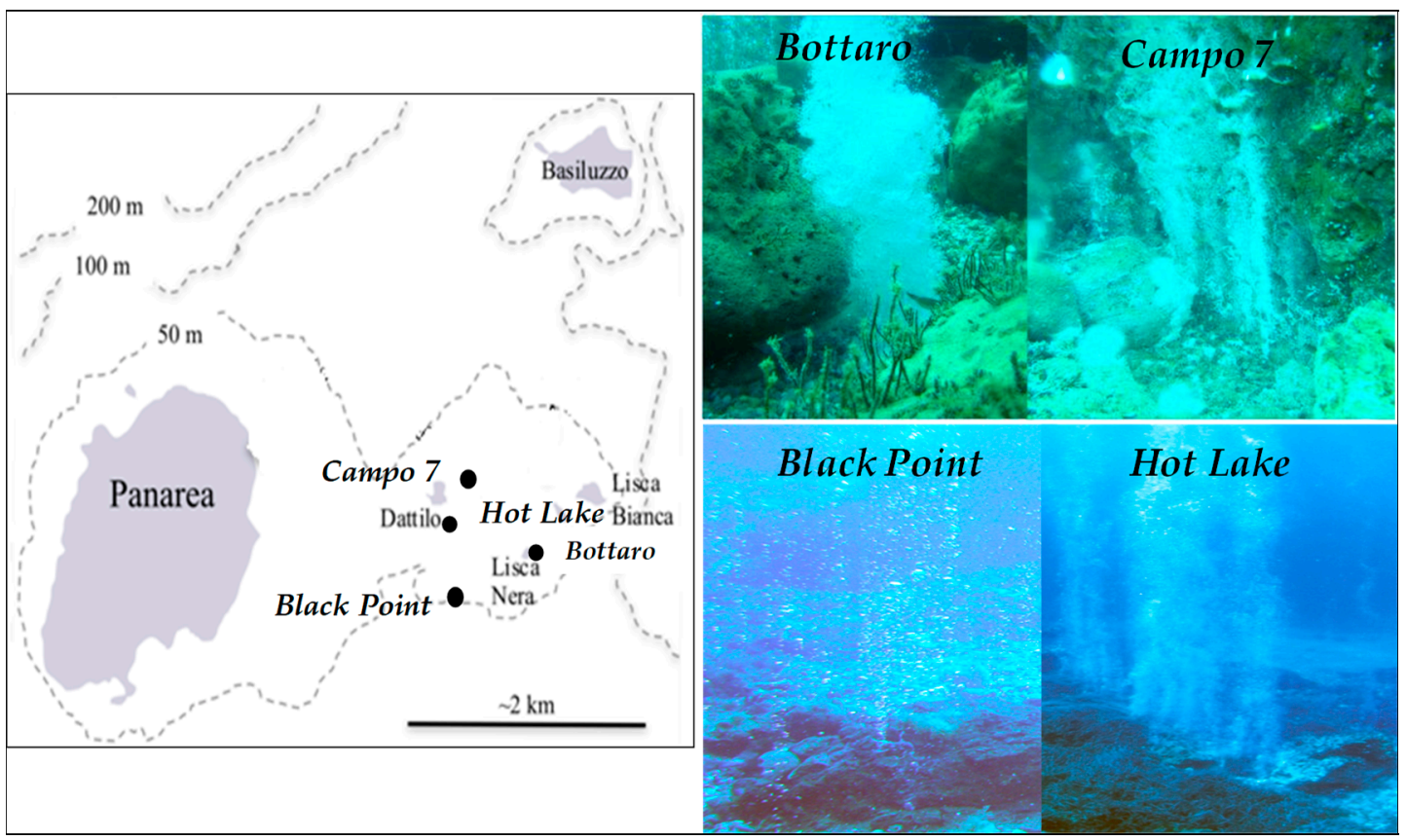

Figure 3. Map of Panarea Island and surrounding islets. Sampling sites' location (closed circles) and vents emissions at Bottaro, Campo 7, Black Point, and Hot Lake.

The exhalative area, which is recognized as the remnants of a crater rim, is delimited by a group of islets (Dattilo, Bottaro, Lisca Bianca, and Lisca Nera) located $2.5 \mathrm{~km}$ east of the main island. The vents occur at shallow depths although hydrothermal deposits and chimneys can be found in deep waters (>400 m; Italiano, personal communication).

The Black Point site, characterized by the presence of black sulfide and manganese incrustations, is a submarine crater in the seafloor located at a depth of $23 \mathrm{~m}$, and it extends about $25 \mathrm{~m}$ in the north-south and about $20 \mathrm{~m}$ in the east-west directions $[14,21,60]$. When compared to other investigated shallow vents in the same area of Panarea, fluids from Black Point vents are characterized by the highest temperatures $\left(120\right.$ and $\left.130^{\circ} \mathrm{C}\right)$ and the lowest $\mathrm{pH}(2.4$ and 3.3) (Table 3).

Table 3. Analytical data of hydrothermal fluids emitted from vents of Panarea Island and collected sample type (F: fluid and S: sediment).

\begin{tabular}{|c|c|c|c|c|c|c|c|c|c|}
\hline \multirow[b]{2}{*}{ Site } & \multirow[b]{2}{*}{ Sample Type } & \multicolumn{4}{|c|}{ Physical and Chemical Properties of Fluid } & \multicolumn{3}{|c|}{ Gas Concentration in Vol\% } & \multirow[b]{2}{*}{ Reference } \\
\hline & & $\begin{array}{l}\text { Depth } \\
\text { (m) }\end{array}$ & $\begin{array}{c}\mathrm{T} \\
\left({ }^{\circ} \mathrm{C}\right)\end{array}$ & $\mathrm{pH}$ & $\begin{array}{l}\text { Conductivity } \\
(\mathrm{mS} / \mathrm{cm})\end{array}$ & $\mathrm{CH}_{4}$ & $\mathrm{He}$ & $\mathbf{N}_{2}$ & \\
\hline Bottaro & Bottaro1 (F, S) & 8 & 52 & 5.3 & 51.3 & $5.1 \times 10^{-4}$ & $6.0 \times 10^{-4}$ & 0.29 & \multirow[b]{2}{*}{ [12] } \\
\hline Campo 7 & $\begin{array}{c}\text { Campo } 7 \\
(\mathrm{~F}, \mathrm{~S})\end{array}$ & 21 & 65 & 4.9 & 44.7 & bdl & $7.0 \times 10^{-4}$ & bdl & \\
\hline Black Point & BP120 (S) & 23 & 120 & 3.3 & 63.7 & $1.0 \times 10^{-4}$ & bdl & 0.01 & $\begin{array}{c}\text { Unpublished } \\
\text { data }\end{array}$ \\
\hline Black Point & BP130 (F, S) & 23 & 130 & 3.3 & 46.2 & $6.0 \times 10^{-2}$ & $1.0 \times 10^{-3}$ & 0.37 & [21] \\
\hline $\begin{array}{l}\text { Black Point } \\
\text { Vent } 1\end{array}$ & BP74 (F, S) & 23 & 74 & 3.3 & 66 & $9.0 \times 10^{-2}$ & $1.1 \times 10^{-2}$ & 0.44 & \multirow{2}{*}{ [14] } \\
\hline $\begin{array}{l}\text { Black Point } \\
\text { Vent } 2\end{array}$ & BP27 (F, S) & 23 & 27 & 2.4 & 55 & $1.7 \times 10^{-1}$ & $9.6 \times 10^{-3}$ & 0.85 & \\
\hline Hot Lake & HL94 (S) & $\sim 20$ & 94 & 4.7 & 94 & $5.0 \times 10^{-4}$ & nd & 0.5 & \multirow{2}{*}{ [15] } \\
\hline Hot Lake & HL28 (S) & $\sim 20$ & 28.5 & 4.5 & 98 & $5.0 \times 10^{-4}$ & nd & 0.5 & \\
\hline
\end{tabular}

bdl: below the detection limit. nd: not determined. 
Gases are mainly composed of $\mathrm{CO}_{2}$. Concentrations of $\mathrm{CH}_{4}$ and He from Black Point were higher than those reported from the exhalative area at Bottaro and Campo 7 vents. Among sites of the submarine hydrothermal system of Panarea, higher redox values (up to about $+300 \mathrm{mV}$ ) were recorded at Black Point [59], indicating the presence of only partial reducing conditions.

Hot Lake is a recently described shallow brine-pool located north-west of the Lisca Bianca and Bottaro islets, off Panarea Island, where emitted fluids ( $\mathrm{pH}$ 4.6) are highly saline and rich in $\mathrm{CO}_{2}$ and $\mathrm{H}_{2} \mathrm{~S}$ [15,59]. The Hot Lake pond is an oval-shaped depression in the seafloor at depth of 20-23 $\mathrm{m}$ [59].

\section{Archaea in Eolian SHS}

\subsection{Archaeal Isolates}

The thermal springs in the Levante harbor of Vulcano Island host dozens of aerobic and anaerobic, thermophilic, and hyperthermophilic microorganisms belonging to bacteria and archaea domains [13]. Thermophilic and hyperthermophilic archaea were isolated from the thermal springs of Vulcano Island, some of them are of interest in pure and applied research (Table 4).

Table 4. Thermophilic and hyperthermophilic archaea isolated from thermal springs of Vulcano Island.

\begin{tabular}{|c|c|c|c|}
\hline Phylum & Class & Species & Reference \\
\hline \multirow{5}{*}{ Crenarchaeota } & \multirow{5}{*}{ Thermoprotei } & Acidianus brierleyi & [63] \\
\hline & & Acidianus infernus & {$[64]$} \\
\hline & & Pyrodictium occultum & {$[65]$} \\
\hline & & Staphylothermus marinus & [66] \\
\hline & & Thermodiscus maritimus & [67] \\
\hline \multirow{10}{*}{ Euryarchaeota } & \multirow{2}{*}{ Archaeoglobi } & Archeoglobus fulgidus & [68] \\
\hline & & Ferroglobus placidus & [69] \\
\hline & Methanococci & Methanococcus aeolicus PL1/5H & [70] \\
\hline & \multirow{6}{*}{ Thermococci } & Palaeococcus helgesonii & [71] \\
\hline & & Pyrococcus furiosus & [72] \\
\hline & & Pyrococcus woesei & [73] \\
\hline & & Thermococcus acidaminovorans & [74] \\
\hline & & Thermococcus alcaliphilus & [75] \\
\hline & & Thermococcus celer & [76] \\
\hline & Thermoplasmata & Thermoplasma volcanium & [77] \\
\hline
\end{tabular}

The first isolated organism at temperatures above $103{ }^{\circ} \mathrm{C}$ was the sulfur-reducing archaeon Pyrodictium occultum [65] with optimal growth temperature of $105^{\circ} \mathrm{C}$. The furious fireball, Pyrococcus furiosus (optimal growth temperature of $100^{\circ} \mathrm{C}$ ) [72], is the source of a very thermostable, commercially available DNA polymerase. Archaeoglobus fulgidus still holds the record as the highest temperature marine sulfate reducer, able to oxidize $\mathrm{H}_{2}$ [68], and Ferroglobus placidus $\left(65-95^{\circ} \mathrm{C}\right)$ couples nitrate reduction with iron oxidation [69].

Several Eolian isolates were closely related to those isolated from deep-sea locations. Among them, Methanococcus aeolicus PL-15/H, a CO 2 -reducing methanogen isolated from Eolian marine sediments [70], producing three different restriction enzymes, was closely related to two strains from sediments taken from the Nankai Trough near the coast of Japan. The new species Palaeococcus helgesonii, one of the rare oxygen tolerant hyperthermophiles, was isolated from a geothermal well of Vulcano Island [71]. This species belongs to the same genus first isolated from a deep-sea hydrothermal vent chimney 
in Japan [78]. All these species make the Levante harbor of Vulcano Island the "type locality" for cultivated hyperthermophiles.

From Panarea submarine vents ( $20 \mathrm{~m}$ depth, fluid temperature $\left.80^{\circ} \mathrm{C}\right)$, Amend and colleagues (personal communication) isolated Thermococcus barossii, T. celer, T. peptonophilus, T. profundus, and T. stetteri, and two strains closely related to Thermococcus retrieved in Loihi Seamount (Hawaii).

Due to the frequent isolation of archaea from Eolian shallow hydrothermal vents, it was assumed that archaea could dominate prokaryotic communities of these sites.

\subsection{Archaeal Community Composition by Culture-Independent Approach}

With advances in culture-independent approaches, which mainly involve techniques based on 16S rRNA genes, an unpredictable, high diversity of microbial community was observed. Archaeal communities at shallow hydrothermal vents are generally found to be less abundant and diverse than the coexisting bacterial communities $[17,79]$. The location and nature of substrata could greatly influence the composition of the archaeal community. As demonstrated by culture-independent $16 \mathrm{~S}$ rRNA gene surveys, thermophiles and hyperthermophiles appear segregated into specific vents, to higher temperature sediments, or internal chimney habitats $[80,81]$. In spite of the great variety of archaea previously isolated by several authors from Vulcano Island, a quite different picture was revealed when molecular methods were used. Samples from hydrothermal seeps of Vulcano Island, investigated by fluorescent in situ hybridization (FISH) using new probes, reported that the diversity of thermophiles at Vulcano was far greater than that represented by cultivated strains [82]. Sequences of DNA extracted from water and sediment samples, and from a geothermal well (Pozzo Istmo), detected a dozen of crenarchaeal, euryarchaeal, and korarchaeal lineages belonging to phylogenetic groups that have no cultured representatives at all [83]. However, one of the sequences from Pozzo Istmo was nearly identical (99\% similarity) to Palaeococcus helgesonii, the euryarchaeon previously isolated from this well [71].

The diversity of both bacteria and archaea thriving at Eolian SHS has been investigated by a fingerprinting method, the denaturing gradient gel electrophoresis (DGGE) $[12,13,21]$. This method is considered one of the most reliable tools for screening and analyzing the microbial community of complex ecosystems. Since this approach allows for the detection of microorganisms only if their proportion is greater than $1 \%$ of the total community, the microbial community diversity is expressed in terms of dominant phylotypes [84]. Fragments resolved by PCR/DGGE of 16S rRNA from bacteria and archaea from sediment samples collected at two Vulcano vents (VS1 and VS2), characterized by different temperatures ( 35 and $60{ }^{\circ} \mathrm{C}$, respectively), indicated that the richness of archaea was lower than that of bacteria [21]. The dominant phylotypes retrieved at these vents were referred to uncultivated clones of Euryarchaeota, with the only exception of one sequence affiliated with Natronorubrum thiooxidans (Halobacteriaceae), a hyperhalophilic archaeon currently detected only in other extreme habitats [85].

More recently, investigations were carried out along a $\mathrm{pH}$ gradient at increasing distance from the primary vent (PV) in the Levante Harbor [62]. DGGE results showed that archaeal richness and diversity increased the narrowing PV site. Archaeal sequences were affiliated with Euryarchaeota and Crenarchaeota and all phylotypes were related to archaea retrieved from extreme environments, most of which were characterized by high temperatures. Sequences were affiliated with members assigned to hyperthermophilic Euryarcheota belonging to the genus Thermococcus (Thermococci) and to the thermophilic genus Methanobrevibacter (Methanobacteria). Norteworthy, more sequences were retrieved within Crenarcheota and related to different members of the class Thermoprotei, with the hyperthermophilic genera Desulfurococcus, Vulcanisaeta and Aeropyrum. Hyperthermophilic Thermococci (Ferroglobus, Palaeococcus, Pyrococcus and Thermococcus) and Thermoprotei (Staphylothermus) were demonstrated using DGGE in sediments from two extremely hot $\left(100^{\circ} \mathrm{C}\right)$ shallow hydrothermal vents of Vulcano Island by Antranikian et al. [86]. Moreover, as revealed using enrichment cultures, the high dominance of Thermococcus and Palaeococcus in the two vents was mainly dependent on the carbon source available, rather than the site temperature [86]. 
The DGGE technique, applied in samples collected from three different vents off Panarea Island (Bottaro1, Campo 7, and Black Point), showed that archaeal populations from the vents were more homogenously distributed in sediments than in fluids, due to the fact that changes in chemical properties and gas composition in fluids were more evident. Phylogenetic analysis of archaeal DGGE 16S rRNA gene sequences revealed that most of sequences were referred to Euryarchaeota, followed by Crenarchaeota. Almost all sequences were affiliated with uncultured clones of archaea mainly retrieved from hot springs and hydrothermal vents of different geographical zones (Table 5)

Table 5. Archaeal distribution arranged by samples collected from Bottaro, Campo 7, and Black Point vent sites, at Panarea system and sample type (F: fluid and S: sediment), as elucidated by PCR/DGGE profiles.

\begin{tabular}{|c|c|c|c|c|c|c|}
\hline Sample & Band & $\begin{array}{l}\text { Sample } \\
\text { Type }\end{array}$ & BLASTn Result & $\begin{array}{l}\text { Percentage } \\
\text { of Identity }\end{array}$ & $\begin{array}{l}\text { Phylogenetic } \\
\text { Affiliation }\end{array}$ & Found in Environment \\
\hline \multirow{7}{*}{ Bottaro $1^{(a)}$} & 3 & $\mathrm{~F}$ & $\begin{array}{l}\text { Uncult. archaeon } \\
\text { clone } 20 \mathrm{c}-54\end{array}$ & 94 & - & $\begin{array}{l}\text { Sediments of the } \\
\text { Aegean Sea }\end{array}$ \\
\hline & 4 & $\mathrm{~F}$ & Uncult. clone $\mathrm{Y} 5 \mathrm{x}$ & 96 & Crenarchaeota & Basaltic flanks \\
\hline & 5 & $\mathrm{~F}$ & $\begin{array}{l}\text { Uncult. archaeon } \\
\text { clone VulcPIw. } 66\end{array}$ & 96 & - & Geothermal well \\
\hline & 6 & $\mathrm{~F}$ & $\begin{array}{l}\text { Uncult. clone } \\
\text { a87R72 }\end{array}$ & 96 & Euryarchaeota & Basaltic flanks \\
\hline & 7 & $\mathrm{~F}$ & $\begin{array}{l}\text { Uncult. clone } \\
\text { D_A04 }\end{array}$ & 96 & Crenarchaeota & $\begin{array}{l}\text { Hydrothermal Vent, } \\
\text { New Zealand }\end{array}$ \\
\hline & 8 & F & $\begin{array}{l}\text { Paleococcus helgesonii } \\
\text { DSM } 15127\end{array}$ & 96 & Euryarchaeota & Geothermal well \\
\hline & 9 & S & $\begin{array}{l}\text { Uncult. Ferroglobus } \\
\text { sp. clone IAN1-2 }\end{array}$ & 87 & Euryarchaeota & Deep hydrothermal fluids \\
\hline \multirow{2}{*}{ Campo $7^{\text {(a) }}$} & 13 & $\mathrm{~F}$ & Uncult. clone LDS17 & 95 & Euryarchaeota & Dagow Lake \\
\hline & 14 & $S$ & Uncult. clone G37A & 91 & Euryarchaeota & Salt crust \\
\hline \multirow{6}{*}{$\begin{array}{l}\text { Black Point } \\
130^{(b)}\end{array}$} & 1 & $\mathrm{~F}, \mathrm{~S}$ & $\begin{array}{l}\text { Uncult. archaeon } \\
\text { clone pCIRA-E }\end{array}$ & 95 & - & $\begin{array}{l}\text { Deep-sea hydrothermal } \\
\text { field, Japan }\end{array}$ \\
\hline & 2 & $\mathrm{~F}, \mathrm{~S}$ & $\begin{array}{l}\text { Uncult. archeon } \\
\text { clone VulcPIw.164 }\end{array}$ & 94 & - & $\begin{array}{l}\text { Geothermal well on } \\
\text { Vulcano Island, Italy }\end{array}$ \\
\hline & 3 & $\mathrm{~F}, \mathrm{~S}$ & $\begin{array}{l}\text { Uncult. clone } \\
\text { ESYB61 }\end{array}$ & 86 & Euryarchaeota & $\begin{array}{l}\text { Estuarine sediment at the } \\
\text { mouth of Orikasa River }\end{array}$ \\
\hline & 4 & $\mathrm{~F}, \mathrm{~S}$ & $\begin{array}{l}\text { Uncult. archaeon } \\
\text { clone CaR3s.09 }\end{array}$ & 92 & - & Coastal Arctic ecosystem \\
\hline & 5 & $\mathrm{~F}, \mathrm{~S}$ & $\begin{array}{l}\text { Uncult. clone } \\
\text { PNG_TB_4A2.5H2_A3 }\end{array}$ & 90 & Crenarchaeota & $\begin{array}{c}\text { Arsenic-rich sediment } \\
\text { shallow vent, } \\
\text { Papua Guinea }\end{array}$ \\
\hline & 6 & $\mathrm{~F}$ & $\begin{array}{c}\text { Paleococcus helgesonii } \\
\text { DSM } 15127\end{array}$ & 85 & Euryarchaeota & $\begin{array}{l}\text { Geothermal well on } \\
\text { Vulcano Island, Italy }\end{array}$ \\
\hline
\end{tabular}

a: Maugeri et al. [12]. b: Maugeri et al. [21].

Some sequences were only moderately related ( $<95 \%$ similarity) to database entries and therefore they could represent new archaeal taxa. All retrieved uncultered clones were related to Archaea detected at extreme environments, most of which were characterized by high temperature. Only two sequences were related to Palaeococcus helgesonii, the euryarchaeon isolated from a Vulcano Island well [68], demonstrating that Panarea and Vulcano hydrothermal systems may host similar members of archaeal populations. Sequences related to an uncultured Ferroglobus sp. (Archaeoglobi), reported from deep-sea fluids [87], were also retrieved. 


\subsection{Data from Next Generation Sequencing Technologies}

To analyze the real microbial diversity, powerful sequencing technologies have recently been applied to marine samples from various deep-sea hydrothermal vents [39,88-90] and in shallow-water hydrothermal vents [14,17,91-93].

High-throughput sequencing techniques represent powerful tools for studing microbial diversity, since the increased numbers (millions) of operational taxonomic units (OTUs) offer the opportunity of revealing simultaneously a large number of individuals and their taxonomic affiliation [14,94]. To gain a better understanding of microbial diversity associated with Panarea vents, we applied Illumina high-throughput amplicon sequencing of the V3 region of the 16S rRNA gene for bacteria and archaea to samples collected from Black Point [14,95] and Hot Lake sites [15]. This tool enabled us to detect and enumerate also microorganisms occurring at very low relative abundance (lower than $0.01 \%$ ). As resulted by the analysis of high-quality reads, archaea represented a minor component of the prokaryotic community at Black Point (from $0.03 \%$ to $1.6 \%$ of high-quality reads), and Hot Lake (from $0.05 \%$ to $3.5 \%$ ) sites, at both low- and high-temperature conditions.

In fluids emitted at Black Point sites, Euryarchaeota dominated the archaeal community at high $\left(74{ }^{\circ} \mathrm{C}, \mathrm{BPF} 74\right)$ and low $\left(27^{\circ} \mathrm{C}, \mathrm{BPF} 27\right)$ temperatures, Halobacteria were prevalent (Figure 4$)$ and were affiliated with several genera (Haloarcula, Halobacterium, Halobiforma, Halomicrobium, Haloplanus, Halorubrum, and Natronomonas) (Table 6).

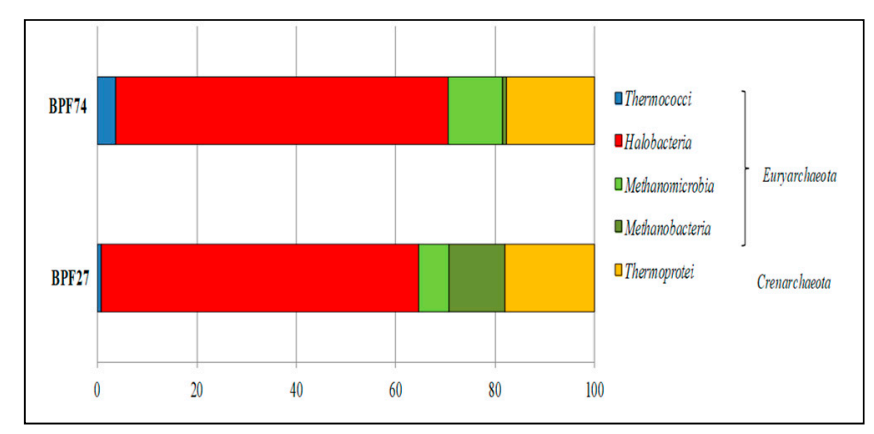

Figure 4. Archaeal community composition in fluids collected from Black Point site at high (BPF74) and low temperature (BPF27).

Sequences referred to class Methanobacteria, with the genus Methanobrevibacter were more abundant in the low-temperature fluid (BPF27), while those affiliated class Methanomicrobia, with the genus Methanosarcina, were prevalent in the high-temperature fluid (BPF74) (Table 6). Sequences affiliated with the Thermococci class, felting into the genus Palaeococcus, were more abundant in the high-than in the low-temperature fluid. All crenarchaeotal sequences were related to hyperthermophilic members of the Thermoprotei class. Among them, the most abundant genus was Staphylothermus (Table 6) of which the type strain Staphylothermus marinus, a strictly anaerobic, heterotrophic, and $\mathrm{S}^{\circ}$-dependent archaeon was isolated from the heated submarine sediments at Vulcano Island [66]. Very few sequences were referred to the genus Thermocladium, firstly isolated from solfataric muds in Japan, and reported as inhabitant of acidic, extremely thermophilic (i.e., $65-80^{\circ} \mathrm{C}$ ), terrestrial hot spring area [96].

A high number of archaeal sequences from sediments collected from BP and HL remained unclassified at the phylum and the class level. Archaeal community composition in the sediment samples from BP and those from HL vents greatly differed, determining distinct communities at the different temperature conditions (Figure 5).

Members of Euryarchaeota dominated the archaeal community associated with sediments at Hot Lake, while Crenarchaeota (Thermoprotei class) prevailed at BP120. The archaeal community composition from the two sites was distinct, since some groups retrieved at BP were not found at HL and vice versa (Table 6 ). 


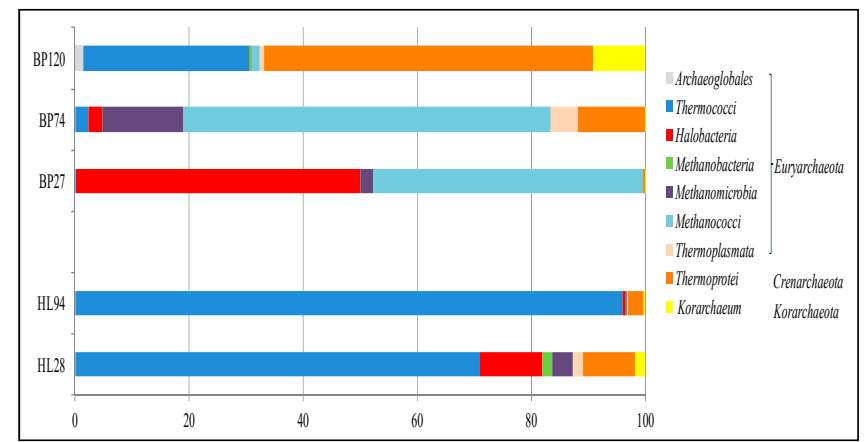

Figure 5. Relative abundances of the archaeal phyla and classes retrieved at different temperature conditions from sediment samples, at Black Point (BP120, BP74, and BP27) and Hot Lake (HL94 and HL28) sites.

Sequences referred to Methanococcus and Methanothermococcus (Methanococci) were found only in sediments from Black Point, while those referred to Halococcus, Methanosphaera, and Methanohalophilus were only retrieved from Hot Lake, whereas Methanobrevibacter (Methanobacteria) were in both sites. Among Methanomicrobia class, the genus Methanococcoides was present in samples (BP74, BP120, and HL94) with higher temperatures. Sample BP120 was the richest in hyperthermophilic genera within Thermococci (Palaeococcus, Pyrococcus, and Thermococcus) and Thermoprotei (Ignicoccus, Ignisphaera, Staphylothermus, Thermodiscus, Thermocladium, Thermofilum, and Vulcanisaeta). The single genus of Korarchaeota, related to "Candidatus Korarchaeum", was retrieved in samples from both Black Point (BPF74 and BP120) and Hot Lake (HL94 and HL28) sites.

Differences in archaeal communities from Black Point and Hot Lake sites emerged more clearly when abundances of archaeal classes were analyzed together with some physical and chemical properties (Table 3) (Figure 6).

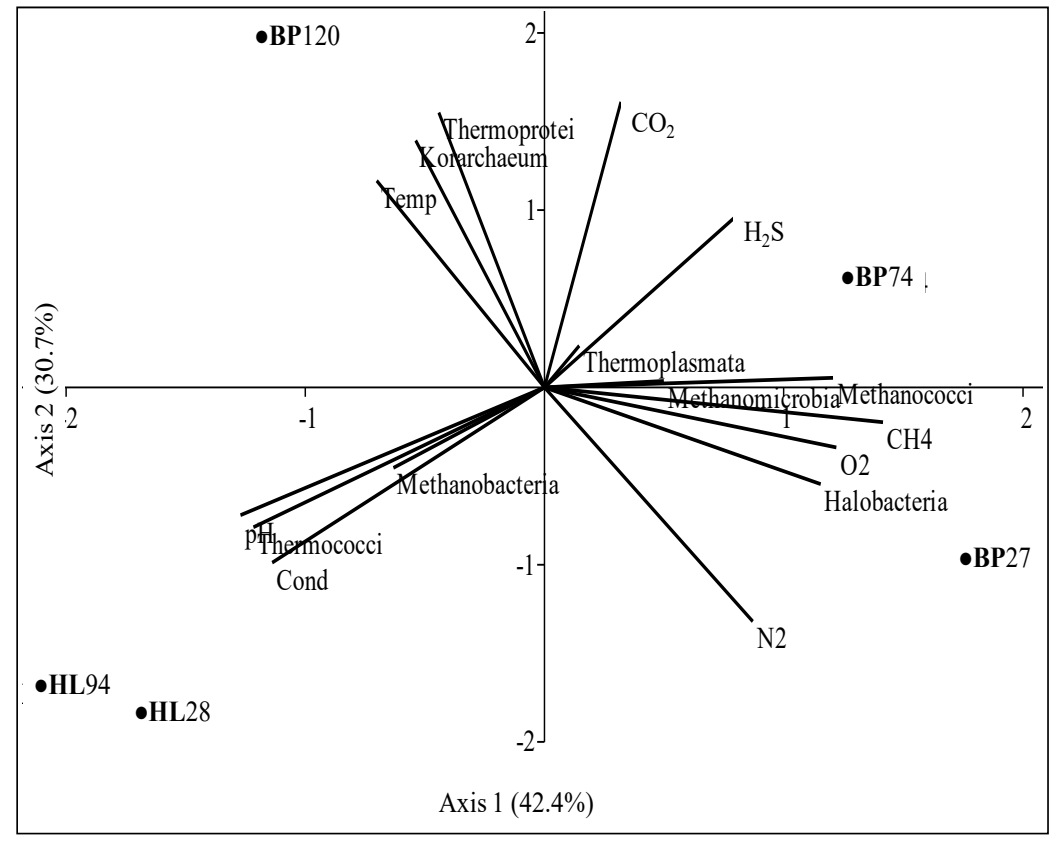

Figure 6. Principal component analysis based on the relative abundances of archaeal classes Thermococci, Halobacteria, Methanobacteria, Methanococci, Methanomicrobia, Thermoplasmata, Thermoprotei, and Korarchaeum, detected in sediments and fluids, and $\mathrm{pH}$, conductivity (Cond), temperature (Temp), $\mathrm{O}_{2}$, $\mathrm{N}_{2}, \mathrm{CH}_{4}, \mathrm{CO}_{2}, \mathrm{H}_{2} \mathrm{~S}$ from BP (BP27, BP74, and BP120) and HL (HL28, HL94) sites. 
Table 6. Archaeal class, order, and genus distribution in fluids and sediments from Black Point (BP120, BP74, and BP27) and Hot Lake (HL94 and HL28) sites, as elucidated by Illumina sequencing technology.

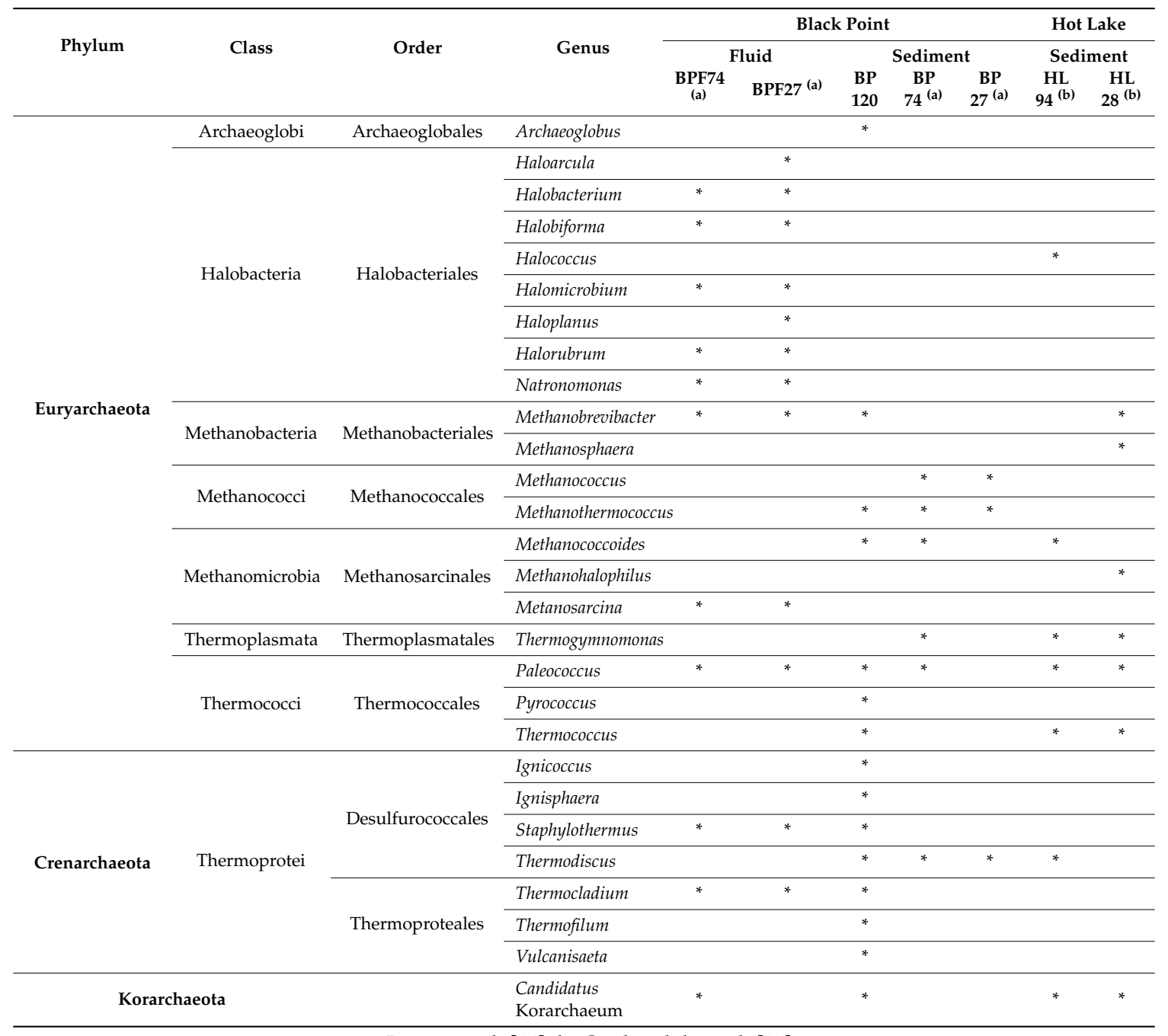

a: Lentini et al. [14]. b: Gugliandolo et al. [15].

As expected, Halobacteria and Methanococci greatly depended on $\mathrm{O}_{2}$ and $\mathrm{CH}_{4}$, respectively, whereas Thermoprotei (Crenarchaeota) and Korarchaeum by temperature. Halobacteria were exclusive in fluids, whereas Methanococci in sediments at BP sites, even if each sample was related to different members at the genus level (Table 6).

Archaeal communities in samples from BP were distinguished from each other. The hottest sample (BP120) was associated with Thermoprotei, and Korarchaeum abundances. This finding distinguished the sample from those previously analyzed from Eolian SHS, but makes it similar to deep-sea hydrothermal locations [97]. Sample BP74 was linked with $\mathrm{CO}_{2}, \mathrm{H}_{2} \mathrm{~S}$, and Thermoplasmata, mainly represented by the moderately thermophilic Thermogymnomonas genus. Members of methanogens, strictly linked to $\mathrm{CH}_{4}$, distinguished BP74 communities from those of the BP27 sample, since abundances of Methanococci were linked to BP74, whereas those of mesophilic Methanomicrobia to BP27.

Despite the great difference in temperature, samples from HL sites grouped together, characterized by higher salinity and $\mathrm{pH}$ values (4.5-4.7) and less $\mathrm{CO}_{2}$ content than BP sites. HL28 and HL94 were strictly associated with Thermococci (mainly represented by Palaeococcus and Thermococcus) whereas Methanobacteria (with genera Methanobrevibacter and Methanosphaera) were distinctive of the coldest site HL28 (Table 6). 


\subsection{Comparison with Archaeal Communities from Other Hydrothermal Vents}

After the definition of the Vulcano Island shallow hydrothermal system as the site with the most isolated hyperthemophiles, more insights on the archaeal community composition of Eolian SHS have been obtained by applying molecular culture-independent techniques. As resolved by Illumina sequencing in Vulcano and Panarea sites, the retrieved archaeal communities appeared remarkably diverse, especially when observed at class level, from each to other, and also from those of different SHS, examined by next generation methods (Table 7).

Archaeal communities of extremely hot hydrothermal vents, with temperatures above $100{ }^{\circ} \mathrm{C}$, are composed by well-known hyperthermophyles. Archaeal communities from two shallow vents at Vulcano were dominated by members of class Thermoprotei and Thermococci [80], with the highly abundant genera Staphylothermus, Thermococcus, Aeropyrum, and Pyrodictium, most of them already isolated from the same area in the past (Table 4).

Differences in samples are also quite distinct among samples from Black Point sites, mainly referred to the occurrence of Crenarchaeota (Thermoprotei) and hyperthermophilic members of Euryarchaeota (Archaeoglobi and Thermococci) at the hottest BP120 site. Although Crenarchaeota are reported as more abundant than Euryarchaeota in cold deep-sea sites [98], and at seamounts in the Tyrrhenian Sea [99], they were generally less abundant than Euryarchaeota at different SHS [16]. Thermoprotei from BP120 were referred to several genera, among them Thermodiscus was the most commonly retrieved genus in samples from both Black Point and Hot Lake sites. Euryarchaeotal Archaeoglobi, mainly referred to the genus Ferroglobus, and Thermocococci, with Palaeococcus and Thermococcus genera, were also reported as the dominant archaeal groups at the RP site of Palaeochori Bay (Milos Island, Greece) [17]. Moreover, also the genus Pyrococcus (Thermocococci) was only retrieved at the hottest site BP120. Our results suggest that the differences observed in the major archaeal populations at Black Point and Palaeochori Bay sites are mainly due to the different temperatures and $\mathrm{pH}$ values, rather than the salinity conditions. The moderately acidophilic and thermophilic, euryarchaeotal genus Thermogymnomonas (Thermoplasmata) was commonly retrieved from samples at Black Point and Hot Lake sites, but not in the RP site of Palaeochori Bay (Milos Island), where indeed it was dominant at the less saline $(\mathrm{W})$ site. The presence at Black Point sites of several strictly anaerobic thermophilic archaeal groups, such as Methanococci (including the genera Methanococcus and Methanothermococcus), Thermococci, and Archaeoglobi indicates that these vents are seeded by subseafloor communities.

Hyperthermophilic members of Thermococci (Palaeococcus and Thermococcus) were also predominant at sites from the Hot Lake thermal brine pool, under high-temperature conditions (HL94). Thermococci have been also reported as dominant in deep-sea high-temperature locations, where they act as prominent degraders of organic matter within marine hot-water ecosystems [78]. The genus Palaeococcus was retrieved as the most abundant genus in all the examined sites of Panarea Island. The isolation and occurrence of sequences referred to Paleococcus hegelsonii indicate that the respiration and/or $S^{\circ}$ - fermentation of complex organic compounds may represent the metabolic key pathways at Eolian Island vents, as well as in other hydrothermal systems $[12,21,71,83]$. The decreasing temperature registered at Hot Lake site was accompanied by a concomitant increasing of diversity (Shannon and evenness indices, Table 7) and a marked shift in the archaeal community composition [15], since the majority of hyperthermophilic members retrieved at high temperature (HL94) was successively substituted by more specific mesophilic archaea of the classes Halobacteria, Methanomicrobia, and Methanobacteria [15].

The occurrence of sequences affiliated to Halobacteria, as demonstrated by different molecular sequencing techniques, confirms that they represent dominant archaeal populations at Panarea system, as well as in the shallow system Kueishan Island, Taiwan [100].

As recently evaluated by $16 \mathrm{~S}$ rRNA gene clone library sequencing, archaeal communities in microbial mats collected from low-temperature, hydrothermal fields of Basiluzzo Islet (Eolian Islands) at different depths (from 26 to $211 \mathrm{~m}$ ), were dominated by Thaumarcheota and Woesearchaeota [92]. 
These results suggest that other than temperature, depth, and salinity, different geochemical factors are essential to constraining the archaeal community associated with Eolian hydrothermal sites.

The single genus of the Korarchaeota phylum, related to "Candidatus Korarchaeum" has been commonly detected in different terrestrial and marine hydrothermal habitats, including vents of Vulcano hydrothermal system [83], sites of Palaeochori Bay (Milos Island) [17], and at hot springs of Yellowstone Park [83,97], indicating a broad diffusion in different hydrothermal systems.

Table 7. Archaeal major components retrieved by next generation sequencing at Vulcano, Black Point, and Hot Lake sites in comparison with those from other shallow vents.

\begin{tabular}{|c|c|c|c|c|c|c|c|c|c|}
\hline Site and Sample & $\begin{array}{l}\text { Depth } \\
\text { (m) }\end{array}$ & $\begin{array}{l}\text { Temp } \\
\left({ }^{\circ} \mathrm{C}\right)\end{array}$ & $\mathrm{pH}$ & $\begin{array}{l}\text { Salinity } \\
\left(\mathrm{Cl}^{-} \mathrm{mM}\right)\end{array}$ & OTUs & $H^{\prime}$ & $J$ & Major Components & Reference \\
\hline Vulcano (Italy) & - & - & - & - & - & - & - & - & - \\
\hline I & 0.7 & 100 & 5.9 & - & - & - & - & $\begin{array}{l}\text { Crenarchaeota } \\
\text { (Thermoprotei), } \\
\text { Euryarchaeota } \\
\text { (Thermococci) }\end{array}$ & [86] \\
\hline II & 0.7 & 100 & 5.9 & - & - & - & - & $\begin{array}{l}\text { Crenarchaeota } \\
\text { (Thermoprotei), } \\
\text { Euryarchaeota } \\
\text { (Thermococci) }\end{array}$ & - \\
\hline $\begin{array}{l}\text { Hot Lake, Panarea } \\
\text { Is (Italy) }\end{array}$ & - & - & - & - & - & - & - & - & - \\
\hline HL94 & $\sim 20$ & 94 & 4.7 & 1292 & 454 & 3.27 & 0.53 & $\begin{array}{l}\text { Euryarcheota } \\
\text { (Thermococci) }\end{array}$ & \multirow[b]{2}{*}{ [15] } \\
\hline HL28 & $\sim 20$ & 28.5 & 4.5 & 1200 & 129 & 4.08 & 0.84 & $\begin{array}{c}\text { Euryarcheota } \\
\text { (Thermococci and } \\
\text { Halobacteria) }\end{array}$ & \\
\hline $\begin{array}{c}\text { Black Point, } \\
\text { Panarea Is (Italy) }\end{array}$ & - & - & - & - & - & - & - & - & - \\
\hline BP74 & 23 & 74 & 3.3 & 547.4 & - & - & - & $\begin{array}{l}\text { Euryarcheota } \\
\text { (Methanococci) }\end{array}$ & \multirow[b]{2}{*}{ [14] } \\
\hline BР27 & 23 & 27 & 2.4 & 583.8 & - & - & - & $\begin{array}{c}\text { Euryarcheota } \\
\text { (Methanococci and } \\
\text { Halobacteria) }\end{array}$ & \\
\hline BP120 & 23 & 120 & 3.3 & 793.8 & - & - & - & $\begin{array}{c}\text { Crenarchaeota } \\
\text { (Thermoprotei), } \\
\text { Euryarcheota } \\
\text { (Archaeoglobi and } \\
\text { Thermococci) }\end{array}$ & This study \\
\hline $\begin{array}{c}\text { Palaeochori, } \\
\text { Milos Is (Greece) }\end{array}$ & - & - & - & - & - & - & - & - & - \\
\hline $\mathrm{RP}^{\text {(a) }}$ & 4.5 & 79 & 5.3 & 745 & 9-14 & $1.9-2.3$ & $0.1-0.2$ & $\begin{array}{c}\text { Euryarcheota } \\
\text { (Archaeoglobi and } \\
\text { Thermococci) }\end{array}$ & [17] \\
\hline $\begin{array}{l}\text { Kueishan Is, } \\
\text { Taiwan (China) }\end{array}$ & - & - & - & - & - & - & - & - & - \\
\hline W & 21 & 49.5 & 4.7 & 971 & 436 & 5.74 & - & $\begin{array}{l}\text { Euryarchaeota } \\
\text { (Halobacteria) }\end{array}$ & [100] \\
\hline
\end{tabular}

a: surface sediments $(0-4.5 \mathrm{~cm})$.

\section{Conclusions}

The Eolian SHS sites, characterized by elevated temperatures and salinity, high concentrations of $\mathrm{CO}_{2}$ and low $\mathrm{pH}$, constitute excellent natural fields to investigate how microorganisms respond to potential global changes, and to study the effects of the acidification and increasing temperature in the oceans.

With the advent of modern molecular techniques, the diversity of archaea has been recognized, but relatively little is already known about the ecological role of archaea at the Eolian SHS. Archaea 
represented a minor component of prokaryotic community at the examined samples from Vulcano [86] and Panarea sites $[12,14,15,92]$, and as resulted by phylogenetic analysis Eolian shallow vents harbor a high diversity of largely unknown archaea. Although many members of archaea have not been cultivated yet, their phylogenetic diversity suggests a greater physiological diversity than previously documented. Such ecosystems therefore represent valuable sources of so-far unknown types of archaea and should be studied further, also including innovative cultivation based approaches and molecular tools targeting functional genes to deeply understand their ecological role in these environments.

Archaea communities residing in hydro-thermal fluids are quite different from those present in sediments primarily due to the fact that fluids are strongly influenced by the mixing with overlying seawater, determining steep geochemical gradients that influence the structure and composition of the resident archaeal communities in each site. The detection in high-temperature samples of members assigned to hyperthermophilic Crenarchaeota (Thermoprotei) and Euryarchaeota (Archaeoglobi and Thermococci) makes Eolian SHS similar to those retrieved from different geographical areas, i.e., from Milos Island. However, at the hot and acidic vents of Black Point sites the presence of several strictly anaerobic thermophilic archaeal groups, such as Thermococci, Archaeoglobi, and Methanococci indicates that these vents are similar to those of deep-sea hydrothermal systems.

Temperature values greatly differed in the different sampling occasions at Panarea sites, and the decrease in temperature in the same site indicates that the supply of geothermal heat to the vents becomes exhausted. The considerable loss of the majority of hyperthermophilic representatives in low-temperature samples was accompanied by an increase in the abundance of more specific mesophilic archaea of the classes Halobacteria, Methanobacteria, and Methanomicrobia. In addition to temperature, other geochemical factors are essential to constraining the archaeal community associated with hydrothermal sites.

Our findings extend our view of archaeal diversity and of their phylogenetic composition in shallow hydrothermal environments. These results may be used as baseline information to follow the microbial community responses to potential global changes and to anthropogenic impacts.

Author Contributions: Conceptualization and data curation, C.G. and T.L.M.; Writing-original draft preparation, C.G. and T.L.M.; Writing-review and editing, C.G. and T.L.M.

Funding: This research received no external funding.

Acknowledgments: We are indebted to Jörg Overmann at the Leibniz-Institute DSMZ German Collection of Microorganisms and Cell Cultures (Braunschweig $\mathrm{GmbH}$, Germany) and Valeria Lentini for their valuable scientific and technical support.

Conflicts of Interest: The authors declare no conflict of interest.

\section{References}

1. Tarasov, V.; Gebruk, A.; Mironov, A.; Moskalev, L. Deep-sea and shallow-water hydrothermal vent communities: Two different phenomena? Chem. Geol. 2005, 224, 5-39. [CrossRef]

2. Jannash, H.W.; Mottl, M.J. Geomicrobiology of deep-sea hydrothermal vents. Science 1985, 229, 717-725. [CrossRef]

3. Karl, D.M. Ecology of free-living hydrothermal vent microbial communities. In The Microbiology of Deep-sea Hydrothermal Vents; Karl, D.M., Ed.; CRC Press: Boca Raton, FL, USA, 1995; pp. 35-124.

4. DeLong, E.F. Archaea in coastal marine environments. Proc. Natl. Acad. Sci. USA 1992, 89, 5685-5689. [CrossRef]

5. Massana, R.; Murray, A.E.; Preston, C.M.; DeLong, E.F. Vertical distribution and phylogenetic characterization of marine planktonic Archaea in the Santa Barbara Channel. Appl. Environ. Microbiol. 1997, 63, 50-56.

6. Murray, A.E.; Preston, C.M.; Massana, R.; Taylor, L.T.; Blakis, A.; Wu, K.; DeLong, E.F. Seasonal and spatial variability of bacterial and archaeal assemblages in the coastal waters near Anvers Island, Antarctica. Appl. Environ. Microbiol. 1998, 64, 2585-2595.

7. Pedrós-Alió, C. Marine microbial diversity: Can it be determined? Trends Microbiol. 2006, 14, $257-263$. [CrossRef] 
8. Gugliandolo, C.; Maugeri, T.L. Chemolithotrophic, sulphur-oxidizing bacteria from a marine, shallow hydrothermal vent of Vulcano (Italy). Geomicrobiol. J. 1993, 11, 109-120. [CrossRef]

9. Gugliandolo, C.; Italiano, F.; Maugeri, T.L.; Inguaggiato, S.; Caccamo, D.; Amend, J.P. Submarine hydrothermal vents of the Aeolian Islands: Relationship between microbial communities and thermal fluids. Geomicrobiol. J. 1999, 16, 105-117. [CrossRef]

10. Maugeri, T.L.; Gugliandolo, C.; Caccamo, D.; Stackebrand, E. A polyphasic taxonomic study of thermophilic bacilli from shallow, marine vents. Syst. Appl. Microbiol. 2001, 24, 451-468. [CrossRef]

11. Manini, E.; Luna, G.M.; Corinaldesi, C.; Zeppilli, D.; Bortoluzzi, G.; Caramanna, G.; Raffa, F.; Danovaro, R. Prokaryote diversity and virus abundance in shallow hydrothermal vents of the Mediterranean Sea (Panarea Island) and the Pacific Ocean (North Sulawesi-Indonesia). Microbial Ecol. 2008, 55, 626-639. [CrossRef]

12. Maugeri, T.L.; Lentini, V.; Gugliandolo, C.; Italiano, F.; Cousin, S.; Stackebrandt, E. Bacterial and archaeal populations at two shallow hydrothermal vents off Panarea Island (Eolian Islands, Italy). Extremophiles 2009, 13, 199-212. [CrossRef]

13. Maugeri, T.L.; Bianconi, G.; Canganella, F.; Danovaro, R.; Gugliandolo, C.; Italiano, F.; Lentini, V.; Manini, E.; Nicolaus, B. Shallow hydrothermal vents in the southern Tyrrhenian Sea. Chem. Ecol. 2010, 26, 285-298. [CrossRef]

14. Lentini, V.; Gugliandolo, C.; Bunk, B.; Overmann, J.; Maugeri, T.L. Diversity of prokaryotic community at a shallow marine hydrothermal site elucidated by Illumina sequencing technology. Curr. Microbiol. 2014, 69, 457-466. [CrossRef]

15. Gugliandolo, C.; Lentini, V.; Bunk, B.; Overmann, J.; Italiano, F.; Maugeri, T.L. Changes in prokaryotic community composition accompanying a pronounced temperature shift of a shallow marine thermal brine pool (Panarea Island, Italy). Extremophiles 2015, 19, 547-559. [CrossRef]

16. Dando, P.; Aliani, S.; Arab, H.; Bianchi, C.; Brehmer, M.; Cocito, S.; Fowler, S.W.; Gundersen, J.; Hooper, L.E.; Kolbl, R.; et al. Hydrothermal studies in the Aegean Sea. Phys. Chem. Earth B Hydrol. Oceans Atmos. 2000, 25, 1-8. [CrossRef]

17. Price, R.E.; Lesniewski, R.; Nitzsche, K.S.; Meyerdierks, A.; Saltikov, C.; Pichler, T.; Amend, J.P. Archaeal and bacterial diversity in an arsenic-rich shallow sea hydrothermal system undergoing phase separation. Front. Microbiol. 2013. [CrossRef]

18. Giovannelli, D.; d'Errico, G.; Manini, E.; Yakimov, M.; Vetriani, C. Diversity and phylogenetic analyses of bacteria from a shallow-water hydrothermal vent in Milos Island (Greece). Front. Microbiol. 2013. [CrossRef]

19. Tarasov, V.G. Effects of shallow-water hydrothermal venting on biological communities of coastal marine ecosystems of the Western Pacific. Adv. Mar. Biol. 2006, 50, 267-421.

20. Hirayama, H.; Sunamura, M.; Takai, K.; Nunoura, T.; Noguchi, T.; Oida, H.; Furushima, Y.; Yamamoto, H.; Oomori, T.; Horikoshi, K. Culture-dependent and-independent characterization of microbial communities associated with a shallow submarine hydrothermal system occurring within a coral reef off Taketomi Island, Japan. Appl. Environ. Microbiol. 2007, 73, 7642-7656. [CrossRef]

21. Maugeri, T.L.; Lentini, V.; Gugliandolo, C.; Cousin, S.; Stackebrandt, E. Microbial diversity at a hot shallow thermal vent in the Southern Tyrrhenian Sea (Italy). Geomicrobiol. J. 2010, 27, 1-11. [CrossRef]

22. Maugeri, T.L.; Lentini, V.; Spanò, A.; Gugliandolo, C. Abundance and diversity of picocyanobacteria in shallow hydrothermal vents of Panarea Island (Italy). Geomicrobiol. J. 2013, 30, 93-99. [CrossRef]

23. Woese, C.R.; Fox, G.E. Phylogenetic structure of the prokaryotic domain: The primary kingdoms. Proc. Natl. Acad. Sci. USA 1977, 74, 5088-5090. [CrossRef]

24. Woese, C.R.; Kandler, O.; Wheelis, M.L. Towards a natural system of organisms: Proposal for the domains Archaea, Bacteria, and Eucarya. Proc. Natl. Acad. Sci. USA 1990, 87, 4576-4579. [CrossRef]

25. Guy, L.; Ettema, T.J.G. The archaeal "TACK" superphylum and the origin of eukaryotes. Trends Microbiol. 2011, 19, 580-587. [CrossRef]

26. Petitjean, C.; Deschamps, P.; Lopez-Garcıa, P.; Moreira, D. Rooting the domain archaea by phylogenomic analysis supports the foundation of the new kingdom Proteoarchaeota. Genome Biol. Evol. 2015, 7, 191-204. [CrossRef]

27. Spang, A.; Saw, J.H.; Jørgensen, S.L.; Zaremba-Niedzwiedzka, K.; Martijn, J.; Lind, A.E.; van Eijk, R.; Schleper, C.; Guy, L.; Ettema, T.J.G. Complex archaea that bridge the gap between prokaryotes and eukaryotes. Nature 2015, 521, 173-179. [CrossRef] 
28. Adam, P.S.; Borrel, G.; Brochier-Armanet, C.; Gribaldo, S. The growing tree of Archaea: New perspectives on their diversity, evolution and ecology. ISME J. 2017, 11, 2407. [CrossRef]

29. Spang, A.; Caceres, E.F.; Ettema, T.J. Genomic exploration of the diversity, ecology, and evolution of the archaeal domain of life. Science 2017, 357, eaaf3883. [CrossRef]

30. MacLeod, F.; Kindler, G.S.; Wong, H.L.; Chen, R.; Burns, B.P. Asgard archaea: Diversity, function, and evolutionary implications in a range of microbiomes. AIMS Microbiol. 2019, 5, 48-61. [CrossRef]

31. Takacs, C.D.; Reysenbach, A.L.; Boone, D.R. Archaeal ecology. Encycl. Life Sci. 2001. [CrossRef]

32. DeLong, E.F.; Taylor, L.T.; Marsh, T.L.; Preston, C.M. Visualization and enumeration of marine planktonic archaea and bacteria by using polyribonucleotide probes and fluorescent in situ hybridization. Appl. Environ. Microbiol. 1999, 65, 5554-5563.

33. Karner, M.B.; DeLong, E.F.; Karl, D.M. Archaeal dominance in the mesopelagic zone of the Pacific Ocean. Nature 2001, 409, 507-510. [CrossRef]

34. Vetriani, C.; Jannasch, H.W.; MacGregor, B.J.; Stahl, D.A.; Reysenbach, A.L. Population structure and phylogenetic characterization of marine benthic archaea in deep-sea sediments. Appl. Environ. Microbiol. 1999, 65, 4375-4384.

35. Molari, M.; Giovannelli, D.; d'Errico, G.; Manini, E. Factor influencing prokaryotic community structure composition in sub-surface coastal sediments. Estuar. Coast. Shelf Sci. 2012, 97, 141-148. [CrossRef]

36. Brochier-Armanet, C.; Boussau, B.; Gribaldo, S.; Forterre, P. Mesophilic Crenarchaeota: Proposal for a third archaeal phylum, the Thaumarchaeota. Nat. Rev. Microbiol. 2008, 6, 245-252. [CrossRef]

37. Takai, K.; Oida, H.; Suzuki, Y.; Hirayama, H.; Nakagawa, S.; Nunoura, T.; Inagaki, F.; Nealson, K.H.; Horikoshi, K. Spatial distribution of marine Crenarchaeota group I in the vicinity of deep-sea hydrothermal systems. Appl. Environ. Microbiol. 2004, 70, 2404-2413. [CrossRef]

38. Agogué, H.; Brink, M.; Dinasquet, J.; Herndl, G.J. Major gradients in putatively nitrifying and non-nitrifying Archaea in the deep North Atlantic. Nature 2008, 456, 788-791. [CrossRef]

39. Campbell, B.J.; Polson, S.W.; Zeigler Allen, L.; Williamson, S.J.; Lee, C.K.; Wommack, K.E.; Cary, S.C. Diffuse flow environments within basalt-and sediment based hydrothermal vent ecosystems harbor specialized microbial communities. Front. Microbiol. 2013, 4, 182. [CrossRef]

40. Barns, S.M.; Fundyga, R.E.; Jeffries, M.W.; Pace, N.R. Remarkable archaeal diversity detected in a Yellowstone National Park hot spring environment. Proc. Natl. Acad. Sci. USA 1994, 91, 1609-1613. [CrossRef]

41. Elkins, J.G.; Podar, M.; Graham, D.E.; Makarova, K.S.; Wolf, Y.; Randau, L.; Hedlund, B.P.; Brochier-Armanet, C.; Kunin, V.; Anderson, I.; et al. A korarchaeal genome reveals insights into the evolution of the Archaea. Proc. Natl. Acad. Sci. USA 2008, 105, 8102-8107. [CrossRef]

42. Brochier, C.; Gribaldo, S.; Zivanovic, Y.; Confalonieri, F.; Forterre, P. Nanoarchaea: Representatives of a novel archaeal phylum or a fast-evolving euryarchaeal lineage related to Thermococcales? Genome Biol. 2005, 6, R42. [CrossRef]

43. Huber, H.; Hohn, M.J.; Rachel, R.; Fuchs, T.; Wimmer, V.C.; Stetter, K.O. A new phylum of Archaea represented by a nano-sized hyperthermophilic symbiont. Nature 2002, 417, 63-67. [CrossRef]

44. Wurch, L.; Giannone, R.J.; Belisle, B.S.; Swift, C.; Utturkar, S.; Hettich, R.L.; Reysenbach, A.L.; Podar, M. Genomics-informed isolation and characterization of a symbiotic Nanoarchaeota system from a terrestrial geothermal environment. Nat. Commun. 2016, 7, 12115. [CrossRef]

45. St John, E.; Liu, Y.; Podar, M.; Stott, M.B.; Meneghin, J.; Chen, Z.; Lagutin, K.; Mitchell, K.; Reysenbach, A.L. A new symbiotic nanoarchaeote (Candidatus Nanoclepta minutus) and its host (Zestosphaera tikiterensis gen. nov., sp. nov.) from a New Zealand hot spring. Syst. Appl. Microbiol. 2019, 42, 94-106. [CrossRef]

46. Prokofeva, M.I.; Kostrikina, N.A.; Kolganovam, T.V.; Tourova, T.P.; Lysenko, A.M.; Lebedinsky, A.V.; Bonch-Osmolovskaya, E.A. Isolation of the anaerobic thermoacidophilic crenarchaeote Acidilobus saccharovorans sp. nov. and proposal of Acidilobales ord. nov., including Acidilobaceae fam. nov. and Caldisphaeraceae fam. nov. Int. J. Syst. Evol. Microbiol. 2009, 59, 3116-3122. [CrossRef]

47. Huber, H.; Stetter, K.O. Desulfurococcales. In The Prokaryotes: Archaea. Bacteria: Firmicutes, Actinomycetes, 3rd ed.; Dworkin, M., Falkow, S., Rosenberg, E., Schleifer, K.-H., Stackebrandt, E., Eds.; Springer: New York, NY, USA, 2006; Volume 7, pp. 52-68.

48. Huber, H.; Huber, R.; Stetter, K.O. Thermoproteales. In The Prokaryotes: Archaea. Bacteria: Firmicutes, Actinomycetes, 3rd ed.; Dworkin, M., Falkow, S., Rosenberg, E., Schleifer, K.-H., Stackebrandt, E., Eds.; Springer: New York, NY, USA, 2006; Volume 7, pp. 10-22. 
49. Itoh, T. The family Thermoproteaceae. In The Prokaryotes: Other Major Lineages of Bacteria and the Archaea, 4th ed.; Rosenberg, E., DeLong, E.F., Lory, S., Stackebrandt, E., Thompson, F., Eds.; Springer: Berlin, Germany, 2014; pp. 389-401.

50. Albers, S.-V.; Siebers, B. The family sulfolobaceae. In The Prokaryotes: Other Major Lineages of Bacteria and the Archaea, 4th ed.; Rosenberg, E., DeLong, E.F., Lory, S., Stackebrandt, E., Thompson, F., Eds.; Springer: Berlin, Germany, 2014; pp. 323-340.

51. Huber, H.; Prangishvili, D. Sulfolobales. In The Prokaryotes: Archaea. Bacteria: Firmicutes, Actinomycetes, 3rd ed.; Dworkin, M., Falkow, S., Rosenberg, E., Schleifer, K.-H., Stackebrandt, E., Eds.; Springer: New York, NY, USA, 2006; Volume 7, pp. 32-51.

52. Brileya, K.; Reysenbach, A.-L. The class Archaeoglobi. In The Prokaryotes: Other Major Lineages of Bacteria and the Archaea, 4th ed.; Rosenberg, E., DeLong, E.F., Lory, S., Stackebrandt, E., Thompson, F., Eds.; Springer: Berlin, Germany, 2014; pp. 15-23.

53. Kurr, M.; Huber, R.; König, H.; Jannasch, H.W.; Fricke, H.; Trincone, A.; Kristjannson, J.K.; Stetter, K.O. Methanopyrus kandleri, gen. and sp. nov. represents a novel group of hyperthermophilic methanogens, growing at $110^{\circ} \mathrm{C}$. Arch. Microbiol. 1991, 156, 239-247. [CrossRef]

54. Schut, G.J.; Lipscomb, G.L.; Han, Y.; Notey, J.S.; Kelly, R.M.; Adams, M.M.W. The order thermococcales and the family thermococcaceae. In The Prokaryotes: Other Major Lineages of Bacteria and the Archaea, 4th ed.; Rosenberg, E., DeLong, E.F., Lory, S., Stackebrandt, E., Thompson, F., Eds.; Springer: Berlin, Germany, 2014; pp. 363-383.

55. Zeng, X.; Birrien, J.L.; Fouquet, Y.; Cherkashov, G.; Jebbar, M.; Quérellou, J.; Oger, P.; Cambon-Bonavita, M.A.; Xiao, X.; Prieur, D. Pyrococcus CH1, an obligate piezophilic hyperthermophile: Extending the upper pressure-temperature limits for life. ISME J. 2009, 3, 873-876. [CrossRef]

56. Takai, K.; Nakamura, K.; Toki, T.; Tsunogai, U.; Miyazaki, M.; Miyazaki, J.; Miyazaki, J.; Hirayama, H.; Nakagawa, S.; Nunoura, T.; et al. Cell proliferation at $122{ }^{\circ} \mathrm{C}$ and isotopically heavy $\mathrm{CH} 4$ production by a hyperthermophilic methanogen under high-pressure cultivation. Proc. Natl. Acad. Sci. USA 2008, 105, 10949-10954. [CrossRef]

57. Italiano, F. Hydrothermal fluids vented at shallow depths at the Aeolian islands: Relationships with volcanic and geothermal systems. In Proceedings of the International Workshop Research in Shallow Marine and Fresh Water Systems, Freiberg, Germany, 14-16 May 2009; pp. 55-60.

58. Italiano, F.; Nuccio, P.M. Geochemical investigations of submarine volcanic exhalations to the east of Panarea, Eolian Islands, Italy. J. Volcanol. Geotherm. Res. 1991, 46, 125-141. [CrossRef]

59. Sieland, R.; Steinbrückner, D.; Hamel, M.; Merkel, B.; Schipek, M. Geochemical investigations and gas quantification of submarine fluid discharges in the hydrothermal system of Panarea (Aeolian Islands, Italy). FOG Freiberg Online Geol. 2009, 22, 87-93.

60. Steinbrückner, D. Quantification of submarine degassing of Panarea Volcano in the Aeolian archipelago, Italy. FOG Freiberg Online Geol. 2009, 23, 11-13.

61. Gugliandolo, C.; Lentini, V.; Maugeri, T.L. PCR-DGGE del 16S rRNA di Batteri e Archea nei siti termali marini dell'Isola di Vulcano (Isole Eolie). In Proceedings of the Joint AIOL-SItE Meeting, Ancona, Italy, 17-20 September 2007; p. 53.

62. Papale, M.; Conte, A.; Savoca, S.; Zammuto, V.; Vizzini, S.; Lo Giudice, A.; Gugliandolo, C. Prokaryotic distribution along a $\mathrm{pH}$ gradient at shallow hydrothermal vent of Vulcano Island (Italy). J. Biol. Res. 2016, $89, \mathrm{~S} 1$.

63. Simmons, S.; Norris, R. Acidophiles of saline water at thermal vents of Vulcano, Italy. Extremophiles 2002, 6, 201-207. [CrossRef]

64. Segerer, A.; Neuner, A.M.; Kristjansson, J.K.; Stetter, K.O. Acidianus infernus gen. nov., sp. nov., and Acidianus brierleyi comb. nov.: Facultatively aerobic, extremely acidophilic thermophilic sulfur-metabolizing archaebacteria. Int. J. Syst. Bacteriol 1986, 36, 559-564. [CrossRef]

65. Stetter, K.O.; Konig, H.; Stackebrandt, E. Pyrodictium gen. nov., a new genus of submarine disc shaped sulphur reducing archaebacteria growing optimally at $105{ }^{\circ} \mathrm{C}$. Syst. Appl. Microbiol. 1983, 4, 535-551. [CrossRef]

66. Fiala, G.; Stetter, K.O.; Jannasch, H.W.; Langworthy, T.A.; Madon, J. Staphylothermus marinus sp. nov. represent a novel genus of extremely thermophilic submarine heterotrophic archaebacteria growing up to $98^{\circ}$ C. Syst. Appl. Microbiol. 1986, 8, 106-113. [CrossRef] 
67. Stetter, K.O. Diversity of extremely thermophilic archaebacteria. In Thermophiles: General, Molecular and Applied Microbiology; Brock, T.D., Ed.; Wiley: New York, NY, USA, 1986; pp. 40-74.

68. Stetter, K.O. Archaeoglobus fulgidus gen. nov., sp. nov.: A new taxon of extremely thermophilic archaebacteria. Syst. Appl. Microbiol. 1988, 10, 172-173. [CrossRef]

69. Hafenbradl, D.; Keller, M.; Dirmeier, R.; Rachel, R.; Roßnagel, P.; Burggraf, S. Ferroglobus placidus gen. nov., a novel hyperthermophilic archaeum that oxidizes $\mathrm{Fe}^{2+}$ at neutral $\mathrm{pH}$ under anoxic conditions. Arch. Microbiol. 1996, 166, 308-314. [CrossRef]

70. Schmid, K.; Thomm, M.; Laminet, A.; Laue, F.G.; Kessler, C.; Stetter, K.O.; Schmitt, R. Three new restriction endonucleases MaeI, MaeII and MaeIII from Methanococcus aeolicus. Nucleic Acids Res. 1984, 12, 2619-2628. [CrossRef]

71. Amend, J.P.; Meyer-Dombard, D.R.; Sheth, S.N.; Zolotova, N.; Amend, A.C. Palaeococcus helgesonii sp. nov., a facultatively anaerobic, hyperthermophilic archaeon from a geothermal well on Vulcano Island, Italy. Arch. Microbiol. 2003, 179, 394-401. [CrossRef]

72. Fiala, G.; Stetter, K.O. Pyrococcus furiosus sp. nov. represents a novel genus of marine heterotrophic archaebacteria growing optimally at $100{ }^{\circ} \mathrm{C}$. Arch. Microbiol. 1986, 145, 56-61. [CrossRef]

73. Zillig, W.; Holz, I.; Klenk, H.P.; Trent, J.; Wunderl, S.; Janekovic, D. Pyrococcus woesei sp. nov., an ultrathermophilic marine archaebacterium, representing a novel order, Thermococcales. Syst. Appl. Microbiol. 1987, 9, 62-70. [CrossRef]

74. Dirmeier, R.; Keller, M.; Hafenbradl, D.; Braun, F.J.; Rachel, R.; Burggraf, S.; Stetter, K.O. Thermococcus acidaminovorans sp. nov., a new hyperthermophilic alkalophilic archaeon growing on amino acids. Extremophiles 1998, 2, 109-114.

75. Keller, M.; Braun, F.J.; Dirmeier, R.; Hafenbradl, D.; Burggraf, S.; Rachel, R. Thermococcus alcaliphilus sp. nov., a new hyperthermophilic archaeum growing on polysulfide at alkaline pH. Arch. Microbiol. 1995, 164, 390-395. [CrossRef]

76. Zillig, W.; Holz, I.; Janekovic, D.; Schafer, W.; Reiter, W.D. The archaebacterium Thermoccoccus celer represents a novel genus within the thermophilic branch of the Archaeabacteria. Syst. Appl. Microbiol. 1983, 4, 88-94. [CrossRef]

77. Segerer, A.; Langworthy, T.A.; Stetter, K.O. Thermoplasma acidophilum and Thermoplasma volcanium sp. nov. from solfatara fields. Syst. Appl. Microbiol. 1988, 10, 161-171. [CrossRef]

78. Takai, K.; Sugai, A.; Itoh, T.; Horikoshi, K. Palaeococcus ferrophilus gen. nov., sp. nov., a barophilic, hyperthermophilic archaeon from a deep-sea hydrothermal vent chimney. Int. J. Syst. Evol. Microbiol. 2000, 50, 489-500. [CrossRef]

79. Sievert, S.M.; Ziebis, W.; Kuever, J.; Sahm, K. Relative abundance of Archaea and Bacteria along a thermal gradient of a shallow-water hydrothermal vent quantified by rRNA slot-blot hybridization. Microbiology 2000, 146, 1287-1293. [CrossRef]

80. Huber, J.A.; Cantin, H.V.; Huse, S.M.; Welch, D.B.; Sogin, M.L.; Butterfield, D.A. Isolated communities of Epsilonproteobacteria in hydrothermal vent fluids of the Mariana Arc seamounts. FEMS Microbiol. Ecol. 2010, 73, 538-549. [CrossRef]

81. Nunoura, T.; Oida, H.; Nakaseama, M.; Kosaka, A.; Ohkubo, S.B.; Kikuchi, T.; Kazama, H.; Hosoi-Tanabe, S.; Nakamura, K.; Kinoshita, M.; et al. Archaeal diversity and distribution along thermal and geochemical gradients in hydrothermal sediments at the Yonaguni Knoll IV hydrothermal field in the Southern Okinawa trough. Appl. Environ. Microbiol. 2010, 76, 1198-1211. [CrossRef]

82. Rusch, A.; Amend, J.P. Order-specific 16S rRNA targeted oligonucleotide probes for (hyper) thermophilic Archaea and Bacteria. Extremophiles 2004, 8, 357-366. [CrossRef]

83. Rogers, K.L.; Amend, J.P. Archaeal diversity and geochemical energy yields in a geothermal well on Vulcano Island, Italy. Geobiology 2005, 3, 319-332. [CrossRef]

84. Muyzer, G.; De Waal, E.C.; Uitterlinden, A.G. Profiling of complex microbial populations by denaturing gradient gel electrophoresis analysis of polymerase chain reaction-amplified genes coding for 16S rRNA. Appl. Environ. Microbiol. 1993, 59, 695-700.

85. Sorokin, D.Y.; Tourova, T.P.; Muyzer, G.M. Oxidation of thiosulfate to tetrathionate by an haloarchaeon isolated from hypersaline habitat. Extremophiles 2005, 9, 501-504. [CrossRef] 
86. Antranikian, G.; Suleiman, M.; Schäfers, C.; ·Adams, M.W.W.; Bartolucci, S.; Blamey, J.M.; Birkeland, N.-K.; Bonch-Osmolovskaya, E.; da Costa, M.S.; Cowan, D.; et al. Diversity of bacteria and archaea from two shallow marine hydrothermal vents from Vulcano Island. Extremophiles 2017, 21, 733-742. [CrossRef]

87. Nakagawa, S.; Takai, K. Deep-sea vent chemoautotrophs: Diversity, biochemistry and ecological significance. FEMS Microbiol. Ecol. 2008, 65, 1-14. [CrossRef]

88. Sogin, M.L.; Morrison, H.G.; Huber, J.A.; Welch, D.M.; Huse, S.M.; Neal, P.R.; Arrieta, J.M.; Herndl, G.J. Microbial diversity in the deep sea and the underexplored "rare biosphere". Proc. Natl. Acad. Sci. USA 2006, 103, 12115-12120. [CrossRef]

89. Huber, J.A.; Mark Welch, D.B.; Morrison, H.G.; Huse, S.M.; Neal, P.R.; Butterfield, D.A.; Sogin, M.L. Microbial population structures in the deep marine biosphere. Science 2007, 318, 97-100. [CrossRef]

90. Meyer, J.L.; Akerman, N.H.; Proskurowski, G.; Huber, J.A. Microbiological characterization of post-eruption "snowblower" vents at Axial Seamount, Juan de Fuca Ridge. Front. Microbiol. 2013. [CrossRef]

91. Zhang, Y.; Zhao, Z.; Chen, C.T.A.; Tang, K.; Su, J.; Jiao, N. Sulfur metabolizing microbes dominate microbial communities in andesite-hosted shallow-sea hydrothermal systems. PLoS ONE 2012, 7, e44593. [CrossRef]

92. Bortoluzzi, G.; Romeo, T.; La Cono, V.; La Spada, G.; Smedile, F.; Esposito, V.; Sabatino, G.; Di Bella, M.; Canese, S.; Scotti, G.; et al. Ferrous iron-and ammonium-rich diffuse vents support habitat-specific communities in a shallow hydrothermal field off the Basiluzzo Islet (Aeolian Volcanic Archipelago). Geobiology 2017, 15, 664-677. [CrossRef]

93. Patwardhan, S.; Foustoukos, D.I.; Giovannelli, D.; Yücel, M.; Vetriani, C. Ecological succession of sulfur-oxidizing Epsilon-and Gammaproteobacteria during colonization of a shallow-water gas vent. Front. Microbiol. 2018, 9. [CrossRef]

94. Bartram, A.K.; Lynch, M.D.J.; Stearns, J.C.; Moreno-Hagelsieb, G.; Neufeld, J.D. Generation of multimillion-sequence $16 \mathrm{~S}$ rRNA gene libraries from complex microbial communities by assembling paired-end Illumina reads. Appl. Environ. Microbiol. 2011, 77, 3846-3852. [CrossRef]

95. Maugeri, T.L.; Gugliandolo, C.; Lentini, V. Diversity of prokaryotes at a shallow submarine vent of Panarea Island (Italy) by high-throughput sequencing. Atti Accad. Peloritana Pericolanti-Cl. Sci. Fis. Mat. Nat. 2013, 91. [CrossRef]

96. Itoh, T.; Suzuki, K.; Takashi, N. Thermocladium modestius gen. nov., sp. nov., a new genus of rod-shaped, extremely thermophilic crenarchaeote. Int. J. Syst. Bacteriol. 1998, 48, 879-887. [CrossRef]

97. Reysenbach, A.L.; Gotz, D.; Yernool, D. Microbial diversity of marine and terrestrial thermal springs. In Biodiversity of Microbial Life; Staley, J.T., Reysenbach, A.L., Eds.; Wiley: New York, NY, USA, 2002; pp. 345-421.

98. DeLong, E.F. Oceans of archaea. ASM News 2003, 69, 503-511.

99. Danovaro, R.; Corinaldesi, C.; Luna, G.M.; Magagnini, M.; Manini, E.; Pusceddu, A. Prokaryote diversity and viral production in deep-sea sediments and seamounts. Deep Sea Res. II 2009, 56, 738-747. [CrossRef]

100. Wang, L.; Cheung, M.K.; Kwan, H.S.; Hwang, J.-S.; Wong, C.K. Microbial diversity in shallow-water hydrothermal sediments of Kueishan Island, Taiwan as revealed by pyrosequencing. J. Basic Microbiol. 2015, 1308-1318. [CrossRef]

(C) 2019 by the authors. Licensee MDPI, Basel, Switzerland. This article is an open access article distributed under the terms and conditions of the Creative Commons Attribution (CC BY) license (http://creativecommons.org/licenses/by/4.0/). 